\title{
2.4 Урахування особливостей виховних концепцій у громадянському вихованні учнів старших класів
}

Слід зазначити, що серед науковців існують певні розбіжності у поглядах на суть виховання, його мету і способи реалізації. У зв'язку з цим можна говорити про наявність різних концепцій виховання.

У рамках цих концепцій можна виділити три базові моделі виховання: директивну, прихованого впливу та сприяння. У відповідності до першої моделі виховання тлумачиться як безпосереднє цілеспрямоване формування особистості відповідно до задуму наставника; до другої - як маніпуляція, прихований вплив на особистість 3 метою розвитку в неї бажаних 3 погляду вихователя якостей; до третьої - як сприяння самоактуалізації особистості, створення умов для спонтанного розвитку ії нахилів та здібностей [51].

Директивна модель виховання. У контексті директивної моделі, яка базується на засадах ортодоксального християнства та соціально-педагогічного детермінізму, вихователь уподібнюється скульптору, який за допомогою певних методів і засобів з необробленої брили творить досконалий образ, заздалегідь сформований у його уяві. Вихованця він розглядає як пасивний, аморфний матеріал, з якого можна «ліпити» все, що завгодно.

Директивна модель виховання грунтується на явному визнанні за вихователем як більш зрілою, досвідченою, знаючою людиною права визначати мету виховання, а також педагогічні шляхи, способи і засоби ії реалізації. В цій моделі від вихованців вимагають виконання розпоряджень і вказівок педагога, визнання його ведучої ролі як людини, що покликана спрямовувати їхній розвиток, розв'язувати важливу соціальну проблему - виховувати інших людей.

Директивне виховання грунтується на припущенні, що для повноцінного життя в суспільстві люди повинні засвоїти певні соціальні ролі (громадянина, члена сім'ї, представника професійної групи тощо). А для цього їм необхідно оволодіти певними способами діяльності і спілкування, нормами поведінки, знаннями і цінностями, що створені попередніми поколіннями і втілюють у собі 
в тому чи іншому обсязі соціокультурний досвід людства. Тобто йдеться про те, що педагог (держава, суспільство) краще, ніж сама дитина, знає, якою їй треба стати, у якому напрямку розвиватися. Вихованець може не усвідомлювати необхідність того шляху розвитку, який визначений міркуваннями педагогічної доцільності.

Громадянське виховання має на меті сприяти соціалізації учня. Соціалізацію розуміємо як процес засвоєння культурних цінностей, формування соціальних якостей, завдяки яким людина стає дієздатним учасником соціальних відносин. Водночас у контексті директивної моделі громадянське виховання учнів старших класів здебільшого набуває форми прямого виховного впливу педагога на вихованця. При цьому наставник не приховує своєї позиції ведучого. Навпаки, він відверто демонструє це учневі, закликаючи і зобов'язуючи його наслідувати його, дотримуватись певних вимог.

Директивне виховання за своєю суттю $є$ нормативним. Його метою є долучення підростаючого покоління до тих надбань історичного досвіду людства, які необхідні для життя в суспільстві. А серед його завдань значне місце посідає введення дитини в світ культури, створити умови для засвоєння нею необхідних моделей поведінки, певних соціальних ролей i функцій, сформувати у неї відповідні риси і моральні переконання. Директивне виховання, яке інколи асоціюється з авторитаризмом, не обов'язково передбачає застосування примусу до вихованців, придушення їх ініціативи і самостійності. Лише у своїй крайній, репресивній формі воно проявляється у жорсткому контролі, диктаті над особистістю дитини. Але в дійсності переважає позитивний, продуктивний варіант, що орієнтує на те, щоб педагог, спираючись на свій авторитет, домагався перетворення вихованця в свого однодумця, партнера в реалізації поставлених ним педагогічних завдань. При цьому обов’язок педагога полягає не в тому, щоб примусити вихованця до певних дій i вчинків, а в тому, щоб зацікавити кожну дитину, обгрунтувати необхідність того, що їй пропонується, сформувати позитивне ставлення до завдань, способів i засобів виховного процесу. 
Серед актуальних проблем директивного виховання виокремлюється неузгодженість та розбіжності природних інтересів дітей і виховних завдань дорослих. Безпосередні інтереси i прагнення дітей часто не збігаються 3 вимогами педагога. В умовах директивного виховання дитина відчуває певний тиск вихователя, який спрямовує іiі розвиток, тією чи іншою мірою обмежує їі свободу, аж ніяк не сприяє соціалізації старшокласника. Вихованець у багатьох випадках звільняється від необхідності робити самостійний вибір, тому що за нього все вирішує вихователь. Він стримує розвиток самостійності дитини, їі здатності жити в умовах свободи і відповідати за свої дії.

У контексті громадянського виховання, говорячи про негативні риси його директивної моделі, слід звернути увагу й нате, що культурні цінності та норми, які старшокласник засвоює в процесі такого виховання, він сприймає найчастіше як «чужі», нав'язані йому ззовні, а не як свої власні. Особливо чітко це виявляється в прилученні дітей до норм і правил поведінки, цінностей, які безпосередньо не пов’язані з реаліями їхнього життя, а привносяться в нього дорослими і у зв’язку з цим вимагають зовнішнього підкріплення. Це становить певні ризики, оскільки метою громадянського виховання, перш за все, є виховання поваги до закону, формування умінь взаємодіяти з суспільством та ухвалювати важливі суспільні рішення, керуючись демократичними принципами та цінностями.

Проте, не варто характеризувати саму по собі директивну модель виховною процесу як «негативну», чи «позитивну». Все залежить від тих ситуацій, у яких ми маємо намір застосувати їі, для вирішення яких завдань і за допомогою яких засобів іï використовують. 3 одного боку, директивна модель дозволяє чітко планувати, контролювати і коректувати розвиток дитини, сприяє засвоєнню об’єктивно значущих елементів культури незалежно під тю наскільки сама дитина усвідомила цю необхідність. Значною мірою саме цим можна пояснити той факт, що директивна модель виховання була і залишається провідною. Водночас, така застосування такої моделі може бути підставою вчинення опору з боку вихованця педагогічним зусиллям вихователя, який нав'язує йому мету 
розвитку. Тому вважаємо лише окремі елементи цієї моделі варто застосовувати у громадянському вихованні учнів старших класів.

Модель прихованого виховного впливу. В контексті цієї моделі виховання розуміється як маніпуляція - прихований вплив педагога на вихованця з метою формування у нього бажаних якостей.

Слід зауважити, що поняття маніпуляції у багатьох гуманістично налаштованих педагогів викликає насторожене ставлення або ж цілковите неприйняття. При цьому під маніпуляцією розуміють так зване корисливе маніпулювання, до якого люди вдаються 3 метою одноосібного виграшу. Насправді, маніпуляція як наукове поняття - це вид психологічного впливу, який забезпечує приховане збудження в іншої людини намірів, що не збігаються з їі актуальними бажаннями. Маніпуляцію здійснює, наприклад, учитель, який приховано створює для учня ситуацію успіху в певній діяльності або ж починає урок з цікавої розповіді, щоб заінтересувати дітей матеріалом, який інакше здався б їм нудним. Навряд чи в цих діях є щось погане. Маніпуляція - це засіб, етична оцінка якого можлива лише в контексті тієї діяльності й тієї міжособистісної взаємодії, в які цей засіб включено. Звичайно, маніпуляції можуть здійснюватися як на користь, так і на шкоду людині. У моделі прихованого виховного впливу під маніпуляцією розуміють ті поширені в педагогічній практиці ситуації, коли вихователь щиро прагне до блага вихованця, але при цьому сам вирішує, у чому це благо полягає. Домагаючись своєї мети, вихователь прагне непомітно для дитини викликати в неї наміри, які не збігаються 3 іiі актуальними прагненнями. В результаті здійснюється приховане програмування думок і прагнень дитини, а з іншого боку - вона не усвідомлює педагогічного впливу і не знає кінцевої мети вихователя.

Модель маніпулятивного виховання постає як досить ефективний спосіб організації взаємин учасників виховного процесу. Вона аж ніяк не передбачає маніпулювання дитиною всупереч iі інтересам. Навпаки, конструктивна маніпуляція у вихованні стає позитивним засобом розвитку особистості, іiі самосвідомості, самостійності та відповідальності. 
Ідея про прихованість виховного впливу як важливу передумову його ефективності висловлювалась багатьма відомими педагогами. В. О. Сухомлинський, наприклад, вважав, що «однією 3 умов високої ефективності педагогічного впливу є обстановка невимушеності цього впливу. Іншими словами, учневі не слід у кожний момент знати, що вчитель його виховує... Виховний намір повинен бути прихований обстановкою дружніх, невимушених взаємин. ...зробити свій виховний задум непомітним - один з дуже важливих елементів педагогічної майстерності».

Дотримуючись моделі прихованого виховного впливу, педагог прагне так організувати виховний процес, щоб не ставити перед вихованцем педагогічної мети в явному вигляді, уникати прямого, нехай і відповідного його інтересам впливу, не демонструвати свою керівну роль у вихованні. Це сприяє формуванню у вихованця самостійності, відповідальності за свої вчинки. Причому сам процес виховання сприймається ним як вияв власної активності, а не результат організаційних впливів педагога.

У контексті маніпулятивної моделі виховання старшокласник виступає суб’єктом педагогічного впливу, тому що суб'єктивно він діє самостійно, не усвідомлюючи, що напрямок і рамки його активності визначає педагог. Це запобігає неузгодженості прагнень учасників виховного процесу, зіткненню їхніх інтересів. У дитини формується здатність жити в умовах свободи, приймати відповідальні рішення, робити самостійний життєвий вибір, незважаючи на те, що цю свободу і самостійність програмує і спрямовує вихователь.

Поняття «маніпуляції» часто тлумачать як негативне. Відомо, що під впливом певних стереотипів люди починають вірити в те, у що до цього не вірили. Тому стереотипи транслюють окремі ЗМI, щоб досягти своїх маніпулятивних цілей. Маніпуляції формують стереотипи. Тому аудиторією, яка мислить стереотипами, легко маніпулювати. В основі стереотипного мислення лежать спрощенні уявлення, образи, які не випливають із власного життєвого досвіду. Вони нав’язуються людині, закріплюються в свідомості. Педагог має довести, що найкращою протидією стереотипам є життєвий досвід та критичне 
мислення.

В історії педагогіки першу серйозну спробу теоретичного осмислення маніпулятивної моделі виховання, не використовуючи самого терміну «маніпуляція», здійснив Ж.-Ж. Руссо у романі «Еміль, або про виховання». На його переконання, головним засобом виховання має бути спрямована свобода. Суть концепції «спрямованої свободи» полягає в прихованій організації вихователем ситуацій, які викликають у вихованця ті чи інші потреби i спонукають його до запланованих вчинків. Маніпулятивна модель виховання в порівнянні 3 директивною створює значно сприятливіші умови для

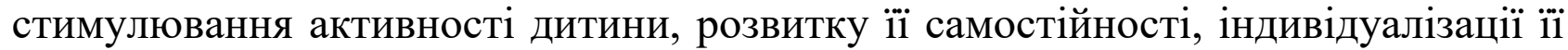
виховання. Будучи педагогікою «спрямованої свободи», вона в прихованій формі зберігає за вихователем функцію керівника й організатора педагогічного процесу, який визначає мету виховання, шляхи і засоби їі досягнення.

Маніпулятивне виховання 3 етичних позицій часто критикують. Стверджують, зокрема, що воно не забезпечує перетворення вихованця в повноправного партнера вихователя, а їхні взаємини - у справді суб'єктносуб’єктні. Непокоїть сам факт прихованості виховного впливу, який часто асоціюється 3 обманом i нещирістю у людських стосунках. Але завдяки маніпулятивній моделі, на нашу думку, можна досягти певного покращення результативності громадянського виховання учнів, зокрема щодо формування поняття суспільної комунікації, свободи слова, етики спілкування, громадянської позиції, критичного сприймання мас-медіа, усвідомлення суспільного добробуту та лобіювання інтересів певних соціальних груп. Елементи цієї виховної моделі, вважаємо, доцільно, якщо ситуація того вимагає, використовувати в громадянському вихованні учнів старших класів.

Вихованець стає повноправним партнером вихователя, а їхні взаємини справді суб’єктно-суб’єктними в рамках третьої моделі виховного процесу моделі сприяння (підтримки). В основі цієї моделі - віра в конструктивне, активне, творче начало людської природи, в їі первісну моральність і доброту, у здатність учня спрямовувати власний розвиток, розуміти власне «Я». 
Відповідно до установок педагогіки сприяння вихователь повинен не вести дитину за собою і навіть не спрямовувати ії розвиток, а йти за нею, підтримувати iï в самореалізації, допомагати їй у розв'язанні власних проблем. Це позиція помічника, який створює умови для саморозвитку особистості: «Мені не треба від тебе більшого, ніж ти сам від себе вимагаєш. Але я радий вислухати тебе і допомогти тобі самому зрозуміти, чого ж ти бажаєш».

Визначені К. Роджерсом умови передбачають стимулювання внутрішніх джерел особистісного розвитку дитини, а саме:

а) природність, щирість, відвертість педагога у вираженні своїх почуттів, його здатність «бути самим собою»;

б) тепла турбота і сприйняття дитини такою, якою вона $є$, повага до дитини як особистості, що заслуговує уваги;

в) емпатія, уміння бачити дитину з її власної точки зору, розуміти ії почуття [52-53].

За цієї моделі першочерговим завданням педагога після знайомства 3 вихованцем $\epsilon$ налагодження контакту, продуктивного спілкування, що грунтується на взаємній повазі і довірі. Наступним кроком є зрозуміти учня. Учитель, спостерігаючи за учнем і спілкуючись з ним, намагається делікатно і ненав'язливо проникнути в його внутрішній світ, з'ясувати його потреби і здібності, розкрити його потенційні можливості, зрозуміти актуальні інтереси, мотиви, якими він керується у своїй поведінці, визначити життєві проблеми, які хвилюють дитину. Після успішного виконання цих завдань, вихователь робить наступні кроки у своїх педагогічних діях. Насамперед він сприяє дитині в самопізнанні, усвідомленні нею набутого досвіду, осмисленні власних інтересів і можливостей, свого місця у соціумі. На цій основі вихованець визначає завдання власного розвитку та соціалізації. Отже, виховну мету педагог визначає не на основі власних уявлень про те. яким має стати вихованець, а з урахуванням його внутрішнього потенціалу та життєвого досвіду. 3'ясувавши разом з учнем мету його громадянського виховання, точніше, створивши умови для визначення учнем шляхів власного громадянського розвитку, педагог сприяє їх реалізації. 
Сприяюча модель виховання практично виключає неузгодженість педагогічних завдань вихователя i життєвих прагнень вихованця, тому що педагогічні завдання формулюються на основі життєвих реалій і за участю самого вихованця. Відтак він сприймає їх не як нав’язані ззовні, а як свої власні. Це запобігає зіткненню прагнень учасників виховного процесу, підвищує його ефективність. При цьому позиція педагога постає як позиція старшого товариша, порадника і помічника вихованця, приховувати ії немає потреби, тому що вона є продуктом їхньої взаємодії.

У процесі сприяючого виховання педагог i вихованець виявляються рівноправними суб'єктами, співтворцями педагогічного процесу, відносини між ними набувають справді суб’єкт-суб’єктного характеру. Учитель виступає як суб’єкт, тому що саме від нього залежить, чи буде обрано дану модель педагогічної взаємодії. При цьому він налаштований на те, щоб не підганяти дитину під державні, суспільні чи свої власні уявлення про виховний ідеал, а свідомо прагне до того, щоб формувати уявлення про майбутній образ дитини, виходячи з неї самої, стимулюючи їі самостійну й дедалі зростаючу участь у цьому процесі. За такого підходу дитина стає справжнім суб'єктом власного розвитку. Саме від iï внутрішнього світу, іiі потенціалу, інтересів і проблем залежить мета виховання і засоби їі досягнення. Дитина перетворюється з засобу реалізації ззовні визначених виховних завдань, як це відбувається в моделі директивного виховання, у суб’єкт і мету власного розвитку.

Історичні корені педагогіки сприяння сягають у глибину століть. Ї̈ елементи наявні, наприклад, у педагогіці Я. А. Коменського, який вбачав педагогічний ідеал у самій людині, що реалізує своє природне обдарування, i трактував виховання як спосіб його розвитку. Сприяти природному розвитку дітей закликав вихователів і реформатор західної педагогіки Ж.-Ж. Руссо. У творчості швейцарського педагога Й. Г. Песталоцці також йдеться про виховання як підтримку дитини в їі самостійному розвитку. Серйозні спроби теоретично обгрунтувати й реалізувати на практиці виховні підходи педагогіки сприяння зробили педагоги-гуманісти на межі XIX-XX ст. в умовах так званої 
«педоцентричної революції», головним ідеологом якої був Дж. Дьюї. У другій половині XX ст. ідеї педагогіки сприяння знайшли своє втілення в «гуманістичній педагогіці», засновниками якої є А. Маслоу, К. Роджерс, Е. Фромм та ін.

Слід підкреслити, що різниця між розглянутими моделями виховання полягає не в мірі симпатії, любові, поваги вихователя до вихованців, а в джерелах визначення і способах реалізації виховних цілей. У кожній з цих моделей педагоги керуються гуманними намірами, піклуються про дітей, однак по-різному бачать шляхи визначення і досягнення виховної мети. В директивній моделі виховні завдання визначаються і відкрито реалізуються вихователем за допомогою прямого впливу на дітей. У маніпулятивній моделі педагогічна мета теж визначається вихователем, однак, досягається приховано, шляхом непрямих впливів, відповідної організації предметного та соціального оточення дітей. У контексті сприяючої моделі виховні завдання визначає сам вихованець, а не педагог, який лише допомагає дитині реалізуватися самостійно.

Закономірно виникає запитання: «Яка 3 розглянутих моделей виховання найкраща для громадянського виховання учнів старших класів? I чи не варто, визначивши найкращу, відмовитись від інших?»

Педагогічні дослідження і практика свідчать, що універсальних, абсолютно ефективних моделей виховання не існує. Кожна з них має певні переваги і сферу свого застосування. Перекручення починаються там, де позитивні моменти того чи іншого підходу переоцінюються. Розгляну ті моделі виховання не слід вважати альтернативними, 3 яких потрібно вибрати «найефективнішу» i відкинути як непродуктивні всі інші. Правильніше розглядати їх як етапи єдиної виховної стратегії, що поступово змінюється одночасно 3 особистісним розвитком вихованців. Доцільність і ефективність тієї чи іншої виховної моделі суттєвим чином залежать від конкретних обставин, рівня особистісної зрілості вихованців, їх вікових та індивідуальних особливостей. Звісно, елементи різних моделей виховання тією чи іншою мірою можуть використовуватися на різних 
етапах громадянського виховання учнів. Але при цьому простежується така закономірність: чим вищого рівня розвитку досягає особистість, тим меншою стає потреба у зовнішньому керівництві, прямих виховних впливах на неї.

Отже, у процесі громадянського виховання слід поступово переходити від прямого формування особистості (директивна модель) через приховані (маніпулятивні) виховні впливи на неї до сприяння іiі саморозвитку. Важливо у міру особистісного становлення вихованця поступово розширювати межі його свободи, надавати йому більший простір для вияву власної ініціативи та самостійності, готувати його до вільного відповідального вибору i самовизначення. 